\title{
Human papillomavirus and skin cancer
}

\author{
Jane M. McGregor and M.H.A. Rustin
}

Department of Dermatology, Royal Free Hospital, London NW3 2QG, UK

\begin{abstract}
Introduction
Established evidence suggests an important role for viruses in the development of some human malignancies. These include Epstein-Barr virus in Burkitt's ${ }^{1}$ and post-transplant lymphoma ${ }^{2}$ and human papillomavirus (HPV) types 16 and 18 in anogenital ${ }^{3}$ and cervical cancer. ${ }^{4}$ Oncogenic HPV types may be involved in the development of skin cancer in patients with epidermodysplasia verruciformis (EV), a rare inherited condition predisposing to virus warts and skin cancer, ${ }^{5}$ and perhaps also in patients immunosuppressed following organ transplantation, but support for this remains controversial. The majority of skin cancers in the general population do not appear to be associated with HPV.
\end{abstract}

\section{Human papillomaviruses}

Papillomaviruses are small DNA viruses that infect both epidermal and mucosal squamous epithelia. Transmission is by direct contact (person to person or object to person) and is enhanced if the skin is broken or macerated. Approximately $60 \mathrm{HPV}$ types have now been characterized, all of which are trophic for squamous epithelia, although many show marked preference for one anatomical site over another. A small number of HPV types, including types 1, 2, 3, 4 and 10 typically infect keratinizing epithelia (the skin) and account for the majority of cutaneous warts in the general population. ${ }^{6}$ Other rare epidermotrophic HPV types including $5,8,14,17$ and $20^{7.8}$ have been identified in the skin of EV patients, but these types are rarely identified in the skin in the general population, even in immunosuppressed patients. ${ }^{9-11}$ HPV types 6, 11,16 and 18 are trophic for genital mucosa ${ }^{4}$ and are rarely identified in skin.

Papillomavirus replication occurs in fully differentiated keratinocytes and usually results in benign squamous proliferation (a papilloma). Transform-

Correspondence: J.M. McGregor, M.A., M.R.C.P. Received: 20 April 1994 ing HPVs, which may be important in the development of some squamous cell carcinomas, include oncogenic types 5 and 8 (in the skin) and 16 and 18 (in genital mucosa).

\section{Human papillomaviruses and cervical cancer}

To date the most compelling evidence of a role for HPV is in the development of anogenital and cervical cancer. Oncogenic HPV types 16 and 18 are frequently identified in anogenital and cervical tumours whilst 'low-risk' HPV types 6 and 11 are more commonly associated with benign cervical lesions. ${ }^{4}$ The oncogenicity of HPV 16 and 18 resides, at least in part, in the ability of viral encoded E6 and E7 proteins to bind and inactivate? host tumour suppressor proteins (p53 and retinoblastoma, respectively). ${ }^{12}$ HPV-encoded E6 and E7 sequences, critical for the transformation of human keratinocytes in vitro, ${ }^{13}$ are specifically retained and expressed in cervical cell lines and genital tumours. ${ }^{14,15}$ Inactivation of $\mathrm{p} 53$ tumour suppressor protein, in this case through binding to viral oncoproteins rather than gene mutation, appears to be a critical step in the development of diverse malignancies, ${ }^{16}$ including anogenital and cervical carcinomas. ${ }^{17,18}$

\section{Human papillomavirus and skin cancer}

Although in vitro studies ${ }^{13}$ and animal models ${ }^{19}$ suggest that skin cancers may be caused by HPV type 16 and 18 infection, this is not reflected in studies of human skin cancer in the general population. For example, unlike cervical cancer where HPV types 16 or 18 are found in up to $90 \%$ of tumours, HPV 16 has consistently been identified only in peri-ungual squamous cell carcinomas. ${ }^{20-23}$ This is an unusual site for tumour development and probably reflects genital transmission of HPV 16 and 18.

HPV has been found in approximately $10 \%$ of skin cancers at other sites but, of these, no parti- 
cular HPV type predominates. To date HPV type $16 / 18$ has been identified in occasional keratocanthomas, ${ }^{24,25}$ types $2,16^{26,27}$ and $34^{28}$ in Bowen's disease, types $36^{28}$ and $41^{29}$ in actinic keratoses, type $20^{28}$ in basal cell carcinomas, and types $5,{ }^{28} 11,{ }^{30,31}$ $16 / 18^{28,32-35}$ and $41^{29}$ in squamous cell carcinoma. However, the detection of HPV in occasional tumours does not necessarily implicate them in tumorigenesis, since co-existent HPV may contaminate tumour material, especially benign HPV types. Of the skin HPV types only types 5, 8 and 41 are known to be oncogenic in vitro and they are very rarely identified in skin cancers in the general population, although they appear to play an important role in the development of squamous cell carcinomas in EV patients. $^{\text {s }}$

\section{Epidermodysplasia verruciformis}

Two groups of immunosuppressed patients predisposed to skin cancer have been studied extensively in an attempt to establish a role for HPV in tumorigenesis. These are patients with epidermodysplasia verruciformis $(\mathrm{EV})^{5}$ and organ transplant patients, ${ }^{36}$ both of whom develop multiple cutaneous warts and squamous cell carcinomas on sun-exposed sites.

EV patients are not systemically immunosuppressed. Their predisposition to widespread HPV infection and cutaneous malignancy is presumed due to some specific, limited immunological defect, the nature of which is unknown. To date, a number of unusual HPV types have been consistently identified in both benign lesions and squamous cell carcinomas in EV patients, including transforming HPV types 5 and $8{ }^{7.8,37}$ Integration of subgenomic fragments of HPV, retained in primary and metastatic tumour, have recently been demonstrated in some skin cancers from these patients, ${ }^{38}$ consistent with a role for HPV in the development of these tumours. EV is a rare condition, however, and studies are few. We need more research in these patients before a role for HPV can be fully established.

\section{Organ transplant recipients}

Organ transplant patients are a much larger cohort to study. They have a well-documented overall increased risk of malignancy, ${ }^{39}$ but an exceptionally high risk of developing virus-associated tumours including non-Hodgkin's lymphoma ${ }^{40}$ and cervical and anogenital carcinoma. ${ }^{41}$ Since they are also at very high risk of developing cutaneous squamous cell carcinomas, ${ }^{36}$ a role for HPV in the development of these is certainly plausible. Transplant recipients develop multiple cutaneous warts and squamous cell carcinomas, often in very close proximity to each other. ${ }^{36}$ Furthermore, posttransplant squamous cell carcinomas demonstrate some features suggestive of viral infection on microscopic examination. ${ }^{42}$ Direct evidence in support of a viral aetiology is lacking, however. Unlike EV patients where oncogenic HPV types have been isolated from benign cutaneous lesions, presumably precursors to squamous cell carcinomas, cutaneous warts in transplant patients are most frequently caused by common HPV types. ${ }^{9-11}$ Moreover, only approximately $10 \%$ of posttransplant tumours examined to date have contained HPV DNA ${ }^{43-49}$ (and often of benign HPV types $^{10.44 .49-51}$, a figure which does not exceed that found in the general population with skin cancer. Since co-existent virus wart infection is extremely common in transplant patients with skin cancer, the demonstration of HPV DNA in some skin tumours may represent tissue contamination.

Oncogenic HPV types, including $5 / 8^{43,45.46,49}$ and $16 / 18,{ }^{43.46,49}$ have been identified in occasional transplant-associated squamous cell tumours in some studies but many others ${ }^{47,48,52,53}$ have been unable to confirm these findings - even employing the polymerase chain reaction, the most sensitive technique currently available for the detection of single copy DNA. These data are insufficient to support a role for oncogenic HPV in the development of the majority of squamous cell carcinomas following renal allograft transplantation.

\section{Conclusions}

Available data do not support a role for oncogenic HPV in the development of the majority of skin cancers, either in the general population or in organ-transplant recipients. The exception to this may be peri-ungual squamous cell carcinomas where HPV 16 and 18 are consistently identified. It is possible that infection with benign HPV types may be a co-factor in the development of some cutaneous squamous cell cancers, particularly in transplant recipients, but this needs further investigation.

A role for HPV types 5 and 8 in the development of skin cancer in patients with EV seems more probable, although the mechanism by which these oncogenic papillomaviruses transform keratinocytes is not currently known. 
1. Zur Hausen, H., Shculte-Holthausen, H. \& Klein, H. EBVDNA in Burkitt's tumour and anaplastic carcinoma of the nasopharynx. Nature 1970, 228: 1056-1058.

2. Hanto, D.W., Gajl-Peczalska, K.J. \& Frizzera, G. Epstein-Barr (EBV) induced polyclonal and monoclonal B-cell lymphoproliferative diseases occurring after renal transplantion. Ann Surg 1983, 198: 356-369.

3. Zur Hausen, H. \& Schneider, A. The role of papillomaviruses in human anogenital cancer. In: Salzman, N.P. \& Howley, P.M. (eds) Papillomaviruses. Plenum Press, New York, 1987, p. 245.

4. Vousden, K.H. Human papillomaviruses and cervical carcinoma. Cancer Cells 1989, 1: 43-50.

5. Lutzner, M.A. \& Blanchet-Bardon, C. Epidermodysplasia verruciformis. Curr Prob Dermatol 1985, 13: 164-185.

6. Cobb, M.W. Human papillomavirus infection. J Am Acad Dermatol 1990, 22: 547-566.

7. Lutzner, M.A., Blanchet-Bardon, C. \& Orth, G. Clinical observations, virologic studies, and treatment trials in patients with epidermodysplasia verruciformis, a disease induced by specific human papillomaviruses. $J$ Invest Dermatol 1984, 83: 18S-25S.

8. Ostrow, R.S., Bender, M., Niimura, M. et al. Human papillomavirus DNA in cutaneous primary and metastasized squamous cell carcinoma from patients with epidermodysplasia verruciformis. Proc Natl Acad Sci USA 1982, 79: $1634-1638$.

9. Dyall-Smith, D., Trowell, H. \& Dyall-Smith, M.L. Benign human papillomavirus infection in renal transplant recipients. Int J Dermatol 1991, 30: 785-789.

10. Van der Leest, R., Zackow, K., Ostrow, R., Bender, M., Pass, F. \& Faras, A. Human papillomavirus heterogeneity in 36 renal transplant recipients. Arch Dermatol 1987, 123: 354-357.

11. Rudlinger, R., Smith, I.W., Bunney, M.H. \& Hunter, J.A.A Human papillomavirus infections in a group of renal transplant recipients. $B r J$ Dermatol 1986, 115: 681-692.

12. Howley, P.M., Scheffner, M., Huibregtse, J. \& Munger, K. Oncoproteins encoded by the cancer-associated human papillomaviruses target the products of the retinoblastoma and p53 tumor suppressor genes. Cold Spring Harb Symp Quant Biol 1991, LVI: 149-155.

13. Hawley-Nelson, P., Vousden, K.H., Hubbert, N.L., Lowy, D.R. \& Schiller, J.T. HPV16 E6 and E7 proteins cooperate to immortalize human foreskin keratinocytes. EMBO J 1989, 8 : 3905-3910.

14. Baker, C.C., Phelps, W.C., Lindgren, V., Braun, M.J., Gonda, M.A. \& Howley, P.M. Structural and transcriptional analysis of human papillomavirus type 16 sequences in cervical carcinoma cell lines. J Virol 1987, 61: 962-971.

15. Schwarz, E., Freese, U.K., Gissmann, L. et al. Structure and transcription of human papillomavirus sequences in cervical carcinoma cells. Nature 1985, 314: 111.

16. Nigro, J.M., Baker, A.C. et al. Mutations in the p53 gene occur in diverse human tumour types. Nature 1989, 342: 705-708.

17. Crook, T., Wrede, D., Tidy, J., Scholefield, J., Crawford, L. \& Vousden, K.H. Status of c-myc, p53 and retinoblastoma genes in human papillomavirus positive and negative squamous cell carcinomas of the anus. Oncogene 1991, 6: 1251-1257.

18. Crooke, T., Wrede, D., Tidy, J.A., Mason, W.P., Evans, D.J. \& Vousden, K.H. Clonal p 53 mutation in primary cervical cancer: association with human-papillomavirus-negative tumours. Lancet 1992, 339: 1070-1073.

19. Lambert, P.F., Pan,. H., Pitot, H.C., Liem, A., Jackson, M. \& Griep, A.E. Epidermal cancer associated with expression of human papillomaviris type 16 E6 and E7 oncogenes in the skin of transgenic mice. Proc Natl Acad Sci USA 1993, 90: 5583-5587.
20. Moy, R.L., Eliezri, Y. D. \& Nuovo, G.J. Human papillomavirus type 16 DNA in periungual squamous cell carcinomas. JAMA 1988, 1261: 2669-2673.

21. Guitart, J., Bergfeld, W.F., Tuthill, R.J., Tubbs, R.R., Zienowicz, R. \& Fleeger, E.J. Squamous cell carcinoma of the nail bed: a clinicopathological study of twelve cases. $\mathrm{Br} J$ Dermatol 1990, 123: 215-222.

22. Moy, R.L. \& Quan, M.B. The presence of human papillomavirus type 16 in squamous cell carcinoma of the proximal finger and reconstruction with a bilobed transposition flap. J Dermatol Surg Oncol 1991, 17: 171-175.

23. Ashinoff, R., Li, J.J. \& Jacobson, M. Detection of human papillomavirus DNA in squamous cell carcinoma of the nail bed and finger determined by polymerase chain reaction. Arch Dermatol 1991, 127: 1813-1818.

24. Magee, K.L., Rapini, R.P. \& Duvic, M. Human papillomavirus associated with keratoacanthoma. Arch Dermatol 1989, 125: $1587-1589$.

25. Hopfl, R.M., Schir, M.M. \& Fritsch, P.O. Keratoacanthomas: human papillomavirus associated? Arch Dermatol 1992, 128: 563-564.

26. Pfister, H. \& Haneke, E. Demonstration of human papillomavirus type 2 DNA in Bowens disease. Arch Derm Res 1984, 276: $123-125$.

27. Kettler, A.H., Rutledge, M., Tschen, J.A. \& Buffone, G. Detection of human papillomavirus in non-genital Bowens disease by in-situ DNA hybridisation. Arch Dermatol 1990, 126: $777-781$.

28. Kawashima, M., Favre, M., Obalek, S., Jablonska, S. \& Orth, G. Premalignant lesions and cancers of the skin in the general population: evaluation of the role of human papillomaviruses. J Invest Dermatol 1990, 95: 537-452.

29. Grimmel, M., de Villiers, E.-M., Pawlita, M., Neumann, C.\& Zur Hausen, $H$. Characterisation of a new human papillomavirus type (41) isolated from disseminated warts and the detection of closely related sequences in some squamous cell carcinomas. Int J Cancer 1988, 41: 5-9.

30. Cohen, L.M., Tyring, S.K., Rady, P. \& Callen, J.P. Human papillomavirus type 11 in multiple squamous cell carcinomas in a patient with subacute cutaneous lupus erythematosus. $J$ Am Acad Dermatol 1992, 26: 840-845.

31. Garven, T.C., Thelmo, W.L., Victor, J. \& Pertschuk, L. Verrucous carcinoma of the leg positive for human papillomavirus DNA 11 and 18: a case report. Human Pathol 1991, 22: $1170-1173$.

32. Pierceall, W.E., Goldberg, L.H. \& Ananthaswamy, H.N. Presence of human papilloma virus type 16 DNA sequences in human nonmelanoma skin cancer. J Invest Dermatol 1991, 97: 880-84.

33. Eliezri, Y.D., Silverstein, S.J. \& Nuovo, G.J. Occurrence of human papillomavirus type 16 DNA in cutaneous squamous and basal cell neoplasms. J Am Acad Dermatol 1990, 23: 836-842.

34. Ostrow, R.S., Shaver, M.K., Turnquist, S. et al. Human papillomavirus-16 DNA in a cutaneous invasive cancer. Arch Dermatol 1989, 125: 666-669.

35. Pfister, H. Human papillomaviruses and skin cancer. Semin Cancer Biol 1992, 3: 263-271.

36. Boyle, J., Mackie, R.M. \& Briggs, J.D. Cancer, warts and sunshine in renal transplant patients. Lancet 1984, i: $702-705$.

37. Gassenmaier, A., Lammel, M. \& Pfister, H. Molecular cloning and characterization of the DNAs of human papillomaviruses 19,20 and 25 from a patient with epidermodysplasia verruciformis. J Virol 1984, 52: 1019-1023.

38. Yabe, Y., Tanimura, Y., Sakai, A., Hitsumoto, T. \& Nohara, Ni. Molecular characteristics and physical state of human papillomavirus DNA change with progressing malignancy: studies in a patient with epidermodysplasia verruciformis. Int J Cancer 1989, 43: 1022-1028. 
39. Penn, I. CRC Critical Reviews in Oncogenesis. CRC Press, Boca Raton, 1989, pp. 27-52.

40. Frizzera, G., Hanto, D.W. \& Gajl-Peczalska, K.J. Polymorphic diffuse B-cell hyperplasias and lymphomas in renal transplant recipients. Cancer Res 1981, 41: 4262-4279.

41. Penn, I. Cancers of the anogenital region in renal transplant patients. Cancer 1986, 58: 611-616.

42. Price, M.L., Tidman, M.J., Fagg, N.L.K., Palmer, T.J. \& MacDonald, D.M. Distinctive epidermal atypia in immunosuppression-associated cutaneous malignancy. Histopathology 1988, 13: 89-94.

43. Barr, B.B., McLaren, K., Smith, I.W. et al. Human papillomavirus infection and skin cancer in renal allograft recipients. Lancet 1989, 1: 124-129.

44. Euvrard, S., Chardonnet, Y., Pouteil-Noble, C.P., Kanitakis, J., Thivolet, J. \& Touraine, J.L. Skin malignancies and human papillomavirus in renal transplant recipients. Transplant Proc 1993, 25: 1392-1393.

45. Lutzner, M.A., Orth, G., Dutronquay, V., Ducasse, M.F., Kreis, H. \& Crosnier, J. Detection of human papillomavirus type 5 DNA in skin cancers of an immunosuppressed renal allograft recipient. Lancet 1983, ii: 422-424.

46. Euvrard, S., Chardonnet, Y., Hermier, C., Viac, J. \& Thivolet, J. Warts and epidermoid carcinoma after renal transplantation. Ann Dermatol Venereol 1989, 116: 201 -211.

47. Soler, C., Chardonnet, Y., Euvrard, S., Chignol, M.C. \& Thivolet, J. Evaluation of human papillomavirus type 5 on frozen sections of multiple lesions from transplant recipients with in situ hybridization and non-isotopic probes. Derm 1992, 184: 248-253.
48. Smith, S.E., Davis, I.C., Leshin, B., Fleischer, A., White, W. \& Feldman, S.R. Absence of human papillomavirus in squamous cell carcinomas of nongenital skin from immunocompromised renal transplant patients. Arch Dermatol 1993, 129: $1585-1588$.

49. Euvrard, S. Association of skin malignancies with various and multiple carcinogenic and noncarcinogenic human papillomaviruses in renal transplant recipients. Cancer 1993, 72: 2198-2206.

50. Manias, D.A., Ostrow, R.S., McGlennen, R.C., Estensen, R.D. \& Faras, A.J. Characterization of integrated human papillomavirus type 11 DNA in primary and metastatic tumors from a renal transplant recipient. Cancer Res 1989, 49: 2514-2519.

51. Euvrard, S., Chardonnet, Y., Dureau, G., Hermier, C. \& Thivolet, J. Human papillomavirus type 1-associated squamous cell carcinoma in heart transplant recipient. Arch Dermatol 1991, 127: 559-564.

52. Dyall-Smith, D., Trowell, H., Mark, A. \& Dyall-Smith, M. Cutaneous squamous cell carcinomas and papillomaviruses in renal transplant recipients: a clinical and molecular biological study. J Dermatol Sci 1991, 2: 139-146.

53. McGregor, J.M., Farthing, A., Crook, T. et al. Posttransplant skin cancer: a possible role for $\mathrm{p} 53$ gene mutation but not for oncogenic human papillomaviruses. J Am Acad Dermatol 1994, 30: 701-706. 